\title{
Interesting case studies of conscious uncoupling
}

\author{
D Aheto-Tsegah Golder Associates (Gh) Ltd, Ghana
}

\begin{abstract}
Integrated mine closure has come a long way in recent years. The physical aspect of closure involving land rehabilitation receives more attention in the mining world relative to the socio-economic aspect of closure, which is typically more challenging. This paper reviews the regulations pertaining to mine closure in Ghana and the indicators of social closure impacts that have been reflected in various types of mining community conflicts across Africa and specifically in Ghana. The paper also focuses on some of the strategies two mines in Ghana have adopted to implement sustainable social development plans for their respective host communities in order to improve the socio-economic status of the communities. These strategies were largely implemented during operations and have the potential to be extended into other African mining communities to increase the potential for the development of sustainable post-mining economies.
\end{abstract}

Keywords: mine closure, socio-economic, social closure, community, sustainable

\section{Introduction}

Mining is an industry perceived to wreak significant havoc to the environment (Heikkinen et al. 2008). Although the industry may be considered 'a necessary evil', as the money generated is essential for development, it often disturbs, and sometimes sterilises, large tracts of land and creates huge volumes of waste (Amponsah-Tawiah \& Dartey-Baah 2011).

The social and environmental impacts of mining are felt long after operations have ceased (Burns \& Church 2018). Before proper closure legislation was implemented in mining jurisdictions, the impacts of mining came at a very high cost. Mines were abandoned, mining towns eventually became ghost towns, and numerous environmental issues arose. For example, Whistle Mine in Sudbury, Ontario, carried out studies after it officially closed in 1998 to address a potential acid mine drainage issue. Consequently, approximately $7 \mathrm{Mt}$ of stockpiled acid-generating waste rock dump had to be relocated to an open pit and contained (Vale 2017). The associated costs with relocation of the waste rock perhaps could have been avoided if the mine discovered the acid-generating potential of the waste rock whilst in operation.

The aftermath of such legacies has resulted in the development of regulations that compel mines to pay greater attention to rehabilitation and closure. The closure plan adopted by a mine is largely dependent on the location of the mine and the critical receptors identified in the mine's zone of influence (Wright 2016). However, mines focus on the physical aspects of closure involving land rehabilitation, while underemphasising the socio-economic impacts (Xavier et al. 2015). This may be perhaps due to much higher complexities when dealing with humans. Nevertheless, Heikkinen et al. (2008) suggest that mining can have a positive socio-economic impact to dependent communities especially over the long term by effecting the necessary transformation for socio-economic independence. However, the implementation of sustainable solutions requires planning and assessment of the options ahead of closure (Heikkinen et al. 2008).

In the author's opinion, careful closure planning and regulations could make post-mining communities socio-economically sustainable. Post-mining lands could also be made beneficial to adjoining communities. Regulations or legislation play an important role in ensuring successful mine closure. Although they are specific to different locations, they all broadly aim to achieve sustainability of the physical environment and socio-economic activities of communities. This process involves activities and procedures through operations, production cessation, to relinquishment of lease using an integrated approach (Heikkinen et al. 2008). The author is of the view that socio-economic strategies especially must be implemented and 
evaluated at the initial stage of mining and concurs with the definition of mine closure by the International Council on Mining of Metals (ICMM):

"A dynamic process that considers environmental, social and economic aspects at an early stage of mine development and is fully incorporated into mine planning." ICMM (2019)

\subsection{Mine closure regulations in Ghana}

Ghana has a long history (over 100 years) of gold mining. Under British Colonial rule, it was aptly named the Gold Coast. Ghana has over 20 large-scale mines and about 600 small-scale mining groups (Amponsah-Tawiah \& Dartey-Baah 2011). Out of the 20 large-scale mining companies 12 produce gold (https://ghanachamberofmines.org), making Ghana the second largest producer of gold in Africa after South Africa (Ababio 2012).

Mine closure in Ghana is largely governed by the Mines and Minerals Commission and the Ghana Environmental Protection Agency (Traore 2016). These two bodies have the following two sets of regulations for mining:

- 'The Minerals and Mining (Health, Safety and Technical) Regulations, 2012 (LI 2182)', which devotes a section to the physical aspects of mine closure for specific domains such as tailings storage facilities, waste rock dumps and open pits. These regulations broadly define the closure scenarios for the various domains.

- 'Schedule 1 of the Environmental Assessment Regulations, 1999 (LI 1652)', which lists all undertakings that require an environmental impact assessment (EIA). Under this regulation, a party that wishes to undertake a project related to mining will mandatorily undertake an EIA, which must also address the closure of the undertaking.

The above descriptions indicate that mine closure regulations in Ghana are inadequate to provide the framework for sustainable post-closure socio-economic transformation for these mining communities. However, experience can be drawn from the history of mining in Ghana to set up a framework for social closure that could transform the mining communities.

\section{Social closure and 'conscious uncoupling'}

Social closure refers to the aspect of closure that relates to the management of social impacts (Burns \& Church 2018). As already discussed, mine closure regulations and guidelines on the physical aspects are not well defined in Ghana and regulations pertaining to social closure are non-existent. As a result, socioeconomic interventions by mines have been largely charitable acts that focus on short-term opportunities and needs without transforming communities into thriving settlements developed on sustainable economic structure (Traore 2016). Successful social closure will require government, communities, and companies to interact in developing and implementing social closure goals.

The planning process must include both the employees of the mine to be closed and the communities in which the mine is located. Generally, the implementation of a social closure plan is challenging as the needs of mining communities change and diversify with time. The process is also often non-sequential, as actions are constantly revised based on feedback from the implementation of planned actions (ICMM 2019). The feedback may influence mine design, operations, rehabilitation and closure as well as the social aspects of mining. It is therefore best described as an 'iterative process' aimed at empowering mining communities (ICMM 2019).

In recent times, the use of the term 'social closure' has been debated due to its ambiguity. When facilities are described as successfully closed and relinquished, it means that they have met defined success criteria, ownership has been transferred to a community or government, and no direct responsibility is borne by the mine. Social closure on the other hand does not necessarily mean that the relationship between the community and company or stakeholders has ended (Burns \& Church 2018). 
Post closure, a community cannot be reverted to its pre-mining state as mining permanently changes its economic structure (Burns \& Church 2018). The term 'social transition to closure' is increasingly being used as a result. ICMM (2019) also notes that closure planning (social closure inclusive) is an 'iterative process' requiring review and update throughout the life of a mine. Together, these definitions emphasise the fact that successful social closure cannot be achieved overnight, but rather involves a systematic approach, continual collaboration and long-term support even after a mine has closed.

The best illustration of the transitioning process involved in social closure planning discussed in this paper is 'conscious uncoupling':

"Conscious uncoupling is a modern term used in breakup or divorce that is characterised by a tremendous amount of goodwill, generosity, and respect, where those separating strive to do minimal damage to themselves, to each other, and to their children (if they have any), as well as intentionally seek to create new agreements and structures so everyone can flourish and thrive moving forward in life." Thomas (2015)

In Thomas's guide, she also mentions that the wounds from a break-up cannot be automatically healed by time; only the people involved can heal the wounds. It is the author's premise that, fundamentally, this is what social closure should aim for - situations in which mines and community people (including former mine employees) consciously work together to ensure that all parties and relevant stakeholders are happy post closure. The mine must seek a good reputation and the community, a sustainable socio-economic structure.

\subsection{Engagements or 'coupling' between mines and communities gone awry}

Around the world the occurrence of riots and protests in mining communities is not uncommon. Perhaps it is even more rampant in nations, such as South Africa, Ghana, Mali, Burkina Faso, that are known historically for the mining of precious metals and stones (Traore 2016). Mining of diamonds in South Africa is reported to have started in 1867 near Hope Town (Kane-Berman 2017). In Ghana, large-scale gold mining is noted to have started in the 1890s. Mali, historically, has been trading in gold since 1324, although commercial gold mining was not reported until 1984 (Rare Gold Nuggets 2015). One would think that certainly the mining companies and the communities in these jurisdictions would be happily 'engaged' by now since they have been 'together' for so long. Tensions between well-known mining companies and communities continue to mount, and in various instances, however, neither the mining companies nor the communities can be completely absolved from blame in this partnership.

In South Africa it is estimated that several protests take place in mining communities every month on various issues that concern the communities (James 2018). For example, residents from Ga-Malukane and Chaba Village took to the streets in September 2016 and blocked a road leading to the Mogalakwena Platinum Mine owned by AngloAmerican. They also set a truck on fire because they believed the mine had failed to deliver regarding issues such as job creation for the communities (James 2018). While the communities admit that some mines do invest in them, they are asking for investments that transform their socio-economic status (James 2018). Relating to the community but not to this protest, AngloAmerican has stated that they have a social and labour plan and have made progress in delivering on their promises. However, they cautioned that they were not fully able to meet resource demands and hence were looking into partnering on development initiatives (AngloAmerican Platinum Limited 2015).

Kalsaka is a community in Burkina Faso known to have been engaged in artisanal small-scale mining (ASM) since the early 1980s. Reportedly, most of the population, dominated by women, depended on small-scale mining (Mazzuca 2017). Amara Mining obtained the right to mine in Kalsaka in 2012 following the government's development agenda to industrialise through large-scale mining. Later in 2013, Amara acquired the Seguenega site. This, however, did not sit well with the host communities, leading to protests. According to the community members, their livelihoods had been lost as land accessible for ASM had been taken over by Amara. Meanwhile, Amara had not honoured its promises of local employment. The open pits that operated in the Kalsaka community have also been left abandoned without rehabilitation after cessation of mining in 2014 (Mazzuca 2017). 
The establishment of Essakane Mine by IAMGOLD resettled 16,000 people; 368 persons were employed by the mine. Following the resettlement process, the mine provided job training, education scholarships and alternative livelihoods for the relocated people. Female artisanal miners were aided to grow vegetables and sell the produce back to the mines. The government of Burkina Faso commended IAMGOLD for its exemplary social commitments. In contrast, the ex-artisanal miners complained that their standard of living had deteriorated since the resettlement. Acts of vandalism at the Essakane Mine occurred in 2015 to induce IAMGOLD to employ more locals at Essakane Mine. Following the protest, the mine donated male and female goats (as well as goat feed) to 241 affected households. These households, however, do not believe that these acts of kindness by the mine are sustainable. In addition, they were not engaged before the inception of the mine (Snorek 2017).

AngloGold Ashanti (AGA), Obuasi Mine, Ghana, has had its share of unsustainable 'engagements' with its host communities throughout its operational life. Two of the closest communities to the Obuasi Mine are Sansu and Anyinam communities. These communities, as a result of their proximity to some of the mine's operational areas, were put on the mine's electricity supply. Anyinam has enjoyed 'free' electricity for over 40 years since the agreement was signed, and the community's size has significantly increased. In fact, a lot of businesses, such as cold stores, printing presses and shops, started operating in Anyinam due to the free electricity. In 2013, the transformer to the community failed because of continuous overloading (Essel 2013).

AGA took the opportunity to explain to the community that the 'free' supply was unsustainable. The community responded with protests. AGA's engagement with Anyinam was futile. The mine was unable to wean the community off the 'free' electricity and replaced the failed transformer with one of higher capacity (Essel 2013).

Again, in 2017, when AGA was restructuring, the company wrote to the leaders of the community to inform them that the mine was unable to continue to supply free electricity due declining business. The community opposed the proposition and threatened to demonstrate for six months if the mine went ahead to put them on the national grid. Engagement with the community is still ongoing to reach a mutual understanding (Kenu 2017).

The abovementioned mine-community conflicts are just a few examples of the attempts by mines to 'uncouple' from host communities. In some cases, the mines are perhaps not doing enough. In other cases, the communities may be seen as problematic or greedy. Who can say which party is to blame? Can Thomas's (2015) definition of 'conscious uncoupling' aptly (which defines the kind of relationship mines and communities must have - that each party should strive to do minimal damage to themselves and to each other and seek to reach agreements for the betterment of each other) help?

\section{Social-economic strategies implemented by some mines in Ghana}

'Conscious uncoupling' can be achieved by strategic social closure planning involving mines, impacted communities, government and all other stakeholders (Heikkinen et al. 2008). In developing countries such as Ghana, social education, health, water and sanitation and local economic development are key developmental issues. The following section looks at the strategies two large mining companies in Ghana have deployed in some of the abovementioned sectors as corporate social responsibility (CSR) initiatives to 'consciously uncouple' from their adjoining communities.

\section{1 $\quad$ AGA Obuasi Mine and the community}

The Obuasi Mine is the oldest in Ghana and is located in the Ashanti Region. Mining operations are said to have started in the 1890s. Ashanti Goldfields Company (AGC) took over operations in 1897. AGC merged with AGA in 2004 (Ababio 2012). The population of the area has increased steadily over the years; reported to be 26,578 in 1960 , the population currently stands at 203,554, making Obuasi the ninth biggest city in Ghana (http://www.statsghana.gov.gh). The mine went into limited operations in 2014 and into care and maintenance from 2016 to 2019. In January 2019, the mine was reopened. 
Obuasi Mine is special in the way the communities are intertwined with the mine. In fact, the Obuasi community is interchangeably referred to as AGC, and AGC also referred to as the Obuasi community (Ababio 2012). Socio-economic activities in Obuasi are largely dependent on the success of the mine. This makes weaning off the community from the mine a challenge. The following describes some of the strategies Obuasi Mine implemented during operations and during the period of limited operations to bring about social development in the Obuasi municipality.

\subsubsection{Small-scale mining on AGA previously owned land}

ASM has always been an issue of national interest in Ghana due to the damaging impact on the environment. The government of Ghana has tried to formalise small-scale mining through laws such as the Minerals and Mining (Licensing) Regulations 2012 (니 2176), but challenges with the bureaucratic legal process, as well as gaps in the enforcement of laws, have encouraged the illegal mining business. Total gold production by both licensed and unlicensed small-scale miners rose from 2.2\% of national production in 1989 to $28 \%$ in 2011 (United Nations Development Program [UNDP] 2017). Small-scale gold mining earned the government USD 95.7 M from 1989 to 1994, whilst proceeds from small-scale diamond mining raked in USD 98.4 M (Gbireh et al. 2007), bringing the total to USD 194.1 over the five-year period. Together the small-scale mining sector industry is reported to employ about $1 \mathrm{M}$ people. These numbers buttress its impact, both negative and positive, on the socio-economic development of Ghana (UNDP 2017). This sector, with proper management, could provide employment opportunities and revenue for Ghana and help achieve the sustainable development goal (SDG) on fostering decent work and economic growth.

Obuasi Mine, which had battled with illegal mining within its concession for a long time, recognised the opportunity in aligning some of its social closure initiatives with the government's agenda on small-scale mining. AGA worked with government to relinquish about $60 \%$ of its $256 \mathrm{~km}^{2}$ concession (AGA 2017a) to locals. Illegal miners were relocated to some of these relinquished concession areas. Currently, AGA reports that there are five ASM mining sites where mining is ongoing under the Minerals Commission. AGA provides technical and logistical advice support when requested (AGA 2017a).

\subsubsection{AGA Malaria Control Program}

Malaria was very prevalent in Obuasi, with over 16,000 malaria cases recorded monthly. About 6,000 of these cases were reported at the AGA Hospital alone. The mine collaborated with the Obuasi Municipal Assembly to launch a malaria control program in 2005 to reduce the incidence by 50\% (GhanaWeb 2005). By 2007, the program had achieved its target of $50 \%$ reduction; by 2016, the cases per month were less than 500 (AngloGold Ashanti 2017b).

Prevention has been done by door-to-door periodic (biannual) indoor residual spraying. AGA engaged the community and partnered with government agencies to fund the program. The program was so successful that it was extended to 14 other districts in the Upper West and Upper East Regions of Ghana. This was done in partnership with Global Fund, National Malaria Control Program, Ghana Health Service and other districtlevel health management teams.

The AGA Malaria Control Program (AGAMal) directly impacts health with a ripple effect on productivity and the economy. The program also creates employment opportunities and has been awarded under the Innovative Integrated Malaria Programming Category by the Private Sector Malaria Prevention Project (Kumsah 2018). Currently, it is an independent subsidiary of AGA that guarantees its existence and continuity post closure (AngloGold Ashanti 2017b).

\subsubsection{Investment fair for employees}

In June 2014, the Obuasi Mine organised an investment and job fair for the ex-employees of the mine and the communities. This was in line with the retrenchment that was ongoing at the time and payout of severances to the employees. The fair brought in consultants from around the country who educated over 
3,000 workers on various financial investment products and on alternative career opportunities after life in AGA (Ghana News Agency [GNA] 2014).

The media covered the event and interviewed people after the fair to evaluate their reactions. The general sentiment of the people was positive, and most of the attendees had high hopes for the future. They deemed the fair a success (GNA 2014). Although it is not known whether most of the attendees of the fair have found career opportunities in non-mining sectors, the fair helped the retrenched employees to mentally and emotionally prepare to venture into other economic activities.

\subsection{Newmont Ahafo South Mine and the community}

Newmont Ahafo South mine is located in the Asutifi North and Tano districts of the Ahafo Region of Ghana. It has been in operation since 2006. The Ahafo Mine operates within 10 communities, and some resettlement was done when Newmont started its operations. The Bono, Ahafo, and Bono East regions in the mining area form a food producing hub, contributing about $30 \%$ of Ghana's agriculture, and farming is the primary economic activity of the host communities.

As a consequence of Newmont's expansion project, some communities (with about 9,500 persons) were resettled. Post resettlement, Newmont collaborated with the Ministry of Food and Agriculture (MoFA) in Ghana and relevant agencies to roll out the Agricultural Improvement and Land Access Program (AILAP), amongst other programs, to restore the livelihoods of the people.

\subsubsection{Agricultural Improvement and Land Access Program}

Agriculture is a major contributor to the GDP of Ghana's economy; however, it has declined from a GDP growth of $7.4 \%$ in 2008 to $2.4 \%$ in 2016 . Farming in Ghana is generally on subsistence scale; farm holdings are typically less than 2 ha in size (MoFA 2016).

The main aim of the AILAP is to increase agricultural diversity and production and also to increase market access relative to what existed before mining commenced. The program engages relevant stakeholders at different levels of the community to provide the necessary resources to establish the agricultural farms. Traditional leaders and land owners are given incentives to contribute land for the affected. Newmont then prepares the land at its own cost, provides seedlings, fertilisers and other essential resources including cash to establish productive farms. As a short-term plan, farmers grow food crops to generate food and income. Over the long term, crops such as cocoa, oil palm and plantain are grown in commercial quantities. MoFA has dedicated extension officers (whose mobility is made easier by motorcycles provided by Newmont) who train the farmers periodically. Over 2,000 farmers are registered under the program. The AILAP has been successful since it was launched, as evidenced by an AILAP farmer receiving a national award for one of the overall best plantain farmers (Newmont Ahafo Ghana 2019).

It is Newmont's expectation that the AILAP will build sustainable livelihoods for the Ahafo farmers. Additionally, the program will lead to better and more profitable agriculture practices post closure than existed before the establishment of the Ahafo Mine.

\subsubsection{Ahafo Linkages Program}

The Ahafo Linkages Program (ALP) is a program signed in cooperation with the International Finance Corporation (IFC). Its primary purpose is to create employment opportunities and increase income (IFC \& Newmont 2009). Implementation of the ALP had the following three components:

1. Build the capacity of local micro, small and medium enterprises (MSME) so that they can be competitive in the bidding of contracts for various services to Newmont and other large companies.

2. Build the capacity of local MSMEs engaged in activities not related to mining.

3. Strengthen a local business association and local consulting services to provide business support services to businesses in Ahafo (IFC \& Newmont 2009). 
Newmont has empowered at least 400 MSMEs who have proceeded to win contracts from the Ahafo Mine. A recipient of the program won an award for Young Entrepreneur of 2012 (Newmont Ahafo Ghana 2019).

The successes of ALP did not come without challenges, however. For example, prior to rolling out the program, some local contractors, who had been awarded contracts with the mine during the construction phase, opposed the new program because it required their bids to be competitive. The local MSMEs believed that the contracts were supposed to be given to them as part of supporting local content but without bidding. Newmont stood its ground and clearly communicated to the local contractors why this was required.

Newmont believes that the 'misunderstanding' with local contractors would not have arisen had the ALP been implemented before the construction phase. That way contracts would have been won competitively from the beginning. To ensure that the program is sustainable post closure, the idea is to hand over the program to another entity that will ensure the sustainability of the program (IFC \& Newmont 2009).

\subsubsection{Ntotroso Community Nursing Training School}

Newmont Ahafo Development Foundation (NADeF) was established to support local sustainable community development projects in the mine's host communities. For every ounce of gold produced by the Ahafo Mine, Newmont contributes USD 1 to NADeF. In addition, 1\% of the Ahafo Mine's net profit is contributed to NADeF. It is estimated that the funds accrued in NADeF amount to USD 17 M (Newmont Ahafo Ghana 2019). So far funds from the foundation have been allocated to various infrastructural projects and educational scholarships. The foundation is managed by an eight-member board; four of the board members are community representatives and the remaining four are from Newmont. Each of the 10 host communities has a committee that advocates for projects to be undertaken in their respective locales (Newmont Ahafo Ghana 2019).

NADeF enabled the Ntotroso Community Nursing Training School to be set up, with the first batch of students admitted in October 2013 (GNA 2013). The nursing training college is the only one in the region, a notable achievement for a population of over $2.3 \mathrm{M}$ spread over a $39,557 \mathrm{~km}^{2}$ area (http://www.statsghana.gov.gh). The set-up of the school was done in collaboration with the Ntotroso Traditional Council, with input from the Ministry of the Ghana Health Service for accreditation of the school (GNA 2013).

After three years of operations, the nursing training college was reported to have a student population of 820 and staff population of 34 (GNA 2016). As reported in an article by Odopa (2015) for The Chronicle, the school was able to admit only $30 \%$ of applicants in 2018 due to limited space and appealed to the government for support. Since then, the government of Ghana has promised to support the nursing training college and donated a bus to this effect.

The establishment of the school addresses various arms of the United Nation's SDGs: employment opportunities are opened and science is encouraged in the region. In addition, the health sector in Ghana is known to lack doctors and nurses, and hence the nursing school aligns with Ghana's developmental goals as well as creates revenue for the Ntotoroso community. Given the impact of the school, it is highly likely to be sustainable long after mining ceases.

\section{$4 \quad$ Lessons and recommendations}

The benefits of the integrated approach and commitment required to achieve social closure and improve the socio-economic status of mining communities cannot be overemphasised. Commitment is required by all arms of society including government, international bodies, local community leaders, community members themselves and mining companies to achieve sustainable projects that transform communities. Projects that involve all relevant stakeholders are often successful. In some cases, they have not only been sustainable but also replicable and extended beyond the borders of mining communities.

There is a lack of regulations, guidelines or policies that could steer the mines in the direction of development and alignment with national developmental goals, especially in Africa. In Ghana, the mines have often chosen the path of least resistance, hence limiting their social development projects to charity work and provisional 
projects, which are not sustainable. Governments should draw up policies that require mines to come up with developmental projects on the national agenda.

Community resistance is usually a result of poor communication between mines and their host communities. Mines sometimes make commitments that are unsustainable and which only encourage community dependence (e.g. AGA's electricity supply to Anyinam). At other times, commitments are made by mines just to get communities to agree to mine proposals, which in the end are not executed. When this happens, community members lose trust in mining companies and governments and become antagonistic towards mining.

One way of averting community riots and protests is planning for social closure before the commencement of a mine. Mine closure planning must necessarily begin the moment mining projects are conceived. The social aspects especially must be amended throughout the life of a mine to meet community needs. For example, the initial client engagement for Newmont's ALP was in 2005 barely a year into the construction phase of the mine, which started in 2004. This suggests that planning for this program was commenced when construction started. Overall, there must be clear communication lines between the mine and the community and mines especially must act on their promises.

Measurable socio-economic changes in mining communities and towns can be achieved when all work together. Successful implementation of social developmental projects involves government, local municipalities, community members, mining companies and all other relevant stakeholders. It is important to align CSR projects with a nation's agenda, as well as SDGs. Non-mining related employment opportunities must be created, and communities must be empowered to create jobs. It is also important to wean off dependent communities during operations so that sustainable ways of ensuring continuity are established before mine closure.

Some mines have successfully implemented projects that will no doubt be continued long after they close. With careful planning and commitment to execution, the mine and the community can 'consciously uncouple', with each party being better off than before the mine existed.

\section{Acknowledgement}

I thank Dr Celestina Allotey for encouraging me to submit this paper, Edna Addai for helping me with the title, and Dr Reginald Hammah, Tim Martin, Ben Asiedu, and the rest of the Golder Associates (Gh) Ltd, Ghana office, for the excellent reviews, which only made this paper better.

\section{References}

Ababio, EOM 2012, 'Gold mining and the development of Obuasi in Adanse', paper presented at the International Mining History Congress, Johannesburg, 17-20 April.

Amponsah-Tawiah, K \& Dartey-Baah, K 2011, 'The mining industry in Ghana: a blessing or a curse', International Journal of Business and Social Science, vol. 2, no. 12, pp. 62-69.

AngloAmerican Platinum Limited 2015, Sustainable Development Report 2015: Driving Change, Defining our Future, viewed 28 March 2019, https://www.angloamericanplatinum.com/ /media/Files/A/Anglo-American-Platinum/documents/1-0-amplats-sd-2015final.pdf

AngloGold Ashanti 2017a, Sustainable Development Report 2017, viewed 23 March 2019, http://www.aga-reports.com/17/sd

AngloGold Ashanti 2017b, Ghana Malaria Programme, viewed 23 March 2019, https://www.anglogoldashanti.com/malaria-controlprogramme-in-ghana/

Burns, C \& Church, J 2018, 'Managing the social impacts of mine closure: How companies can better manage the social impacts of mine closure', Canadian Mining Journal, vol. 139, no. 6, http://www.canadianminingjournal.com/features/managing-thesocial-impacts-of-mine-closure/

Essel, I 2013, 'Anyinam residents clashed with police over AngloGold power cut', Joy Online, viewed 25 March 2019, http://www.myjoyonline.com/news/2013/december-4th/anyinam-residents-clashed-with-police-over-anglogold-power-cut.php

Gbireh, AB, Cobblah, A \& Suglo, RS 2007, 'Analysis of the trends of gold mining in Ghana', Ghana Mining Journal, vol. 9, pp. 38-49.

Ghana News Agency 2013, 'Ntotroso Community Nursing Training School admits first batch in October', GhanaWeb, viewed 30 March 2019, https://www.ghanaweb.com/GhanaHomePage/NewsArchive/Ntotroso-Community-Nursing-School-admits-firstbatch-in-October-268349 
Ghana News Agency 2014, 'AGA organises business fair at Obuasi', News Ghana, viewed 30 March 2019, https://www.newsghana.com.gh/aga-organises-business-fair-at-obuasi/

Ghana News Agency 2016, 'Veep presents bus to Ntotroso Nursing College', viewed 30 March 2019, http://www.ghananewsagency.org/politics/veep-presents-bus-to-ntotroso-nursing-college--108527

GhanaWeb 2005, 'Obuasi Malaria Control Programme to be launched next March', viewed 30 March 2019 , https://www.ghanaweb.com/GhanaHomePage/NewsArchive/Obuasi-Malaria-Control-Programme-to-be-launched-nextMarch-92035

Heikkinen, PM, Noras, P, Salminen, R, Mroueh, GTKUM, Vahanne, P, Wahlstrom, MM, ... Kompa, V 2008, Mine Closure Handbook: Environmental Techniques for the Extractive Industries, viewed 25 March 2019, http://tupa.gtk.fi/julkaisu/erikoisjulkaisu/ej_074.pdf

International Council on Mining of Metals 2019, viewed 25 March 2019, https://www.icmm.com/en-gb/environment/mineclosure/integrated-mining-closure

International Finance Corporation \& Newmont 2009, Creating the Foundations for a Linkage Program in a Rural Setting: Lessons Learned From the Early Stages of the Ahafo Linkages Program in Ghana, viewed 25 March 2019, https://s1.q4cdn.com/259923520/files/doc_downloads/africa/ahafo/linkages/Ahafo-Linkages-Program-Lessons-LearnedIFC-Case-Study-Final_0.pdf

James, N 2018, 'Perceptions mines are not doing enough for nearby communities fuelling protests', Engineering News, viewed 28 March 2019, http://www.engineeringnews.co.za/article/perceptions-mines-are-not-doing-enough-for-nearby-communitiesfuelling-protests-2018-07-20

Kane-Berman, J 2017, 'Mining in SA: Then, now, and into the future - IRR', viewed 29 March 2019, https://www.politicsweb.co.za/documents/mining-in-sa-then-now-and-into-the-future--irr

Kenu, D 2017, 'Anyinam residents protest AngloGold Ashanti's decision to wean them off electricity supply', Graphic Online, viewed 25 March 2019, https://www.graphic.com.gh/news/general-news/anyinam-residents-protest-anglogold-ashanti-s-decisionto-wean-them-off-electricity-supply.html

Kumsah, CE 2018, 'Anglogold Ashanti Obuasi mine's innovative malaria programme receives recognition', Prime News Ghana, viewed 28 March 2019, https://www.primenewsghana.com/general-news/anglogold-ashanti-obuasi-mine-s-innovative-malariaprogramme-receives-recognition.html

Mazzuca, CR 2017, 'Kalsaka/Sega Gold Mines, Amara Mining plc/Perseus Ltd, Burkina Faso', Environmental Justice Atlas, viewed 29 March 2019, https://ejatlas.org/conflict/kalwaka-gold-mine-burkina-faso

Ministry of Food and Agriculture 2016, Agriculture in Ghana: Facts and Figures (2015), viewed 25 March 2019, https://www.agrofoodwestafrica.com/fileadmin/user_upload/messen/agrofood-Westafrica/Brochure/AGRICULTURE-IN-GHANA-Facts-andFigures-2015.pdf

Newmont Ahafo Ghana 2019, Community, viewed 17 July 2019, https://www.newmontgoldcorp.com/wpcontent/uploads/2019/05/NADeF-Factsheet.pdf

Odopa, AG 2015, 'Poor infrastructure limits admission into Ntotroso Nursing College', The Chronicle, viewed 30 March 2019, http://thechronicle.com.gh/index.php/2018/04/11/poor-infrastructure-limits-admission-into-ntotroso-nursing-college/

Rare Gold Nuggets 2015, 'Huge undiscovered gold deposits in Mali', Rare Gold Nuggets, viewed 25 March 2019 , http://raregoldnuggets.com/?p=1838

Snorek, JL 2017, 'Attempting social responsibility at IAMGOLD's mine, Burkina Faso', Environmental Justice Atlas, viewed 29 March 2019, https://ejatlas.org/conflict/gold-and-water-rush-in-burkina-fasos-essakane-mine

Thomas, KW 2015, The Conscious Uncoupling 5 Step Process, viewed 25 March 2019, http://www.consciousuncoupling.com/wpcontent/uploads/2017/04/CUguide.pdf

Traore, M 2016, 'Extractive industries, the state and host communities: a study of gold mining industry in Ghana', Journal of Science and Technology, vol. 36, no. 2, pp. 108-113.

United Nations Development Program 2017, Report of UNDP "Nkitahodie" Policy Dialogue Series 2017: Artisanal and Small-Scale Mining Legal Regime in Ghana: Policy Options for Addressing Gaps and Challenges, viewed 30 March 2019, http://www.gh.undp.org/content/ghana/en/home/library/nkitahodie-policy-dialogue-reports.html

Vale 2017, Decomissioning, viewed 5 June 2019, http://www.vale.com/canada/en/aboutvale/communities/health-safetyenvironment/our-environment/reclamation-and-decommissioning/reclamation-and-decommisioningsudbury/pages/decommissioning.aspx

Wright, A 2016, 'A common-sense approach to mine closure design in the remote Western Australian interior', in AB Fourie \& $\mathrm{M}$ Tibbett (eds), Proceedings of the 11th International Conference on Mine Closure, Australian Centre for Geomechanics, Perth, pp. 635-648.

Xavier, A, Veiga, MM \& van Zyl, D 2015, 'Introduction and assessment of a socio-economic mine closure framework', Journal of Management and Sustainability, vol. 5, no. 1, pp. 38-49. 
